\title{
STRESS RESPONSES OF THREE SPECIES OF CYPRINID: COMMON CARP (Cyprinus carpio), BONYLIP BARB (Osteochilus hasselty), AND TORSORO (Tor soro) SUBJECTED TO OXYGEN DEPLETION
}

\author{
Wahyulia Cahyanti ${ }^{\#}$, Nunak Nafiqoh, and Otong Zenal Arifin \\ Research Intitute of Freshwater Aquaculture and Fisheries Extentions \\ Sempur street Number 1 Bogor
}

(Received: March 11, 2020; Final revised: Sept 9, 2020; Accepted: Sept 14, 2020)

\begin{abstract}
Fish in stressed conditions will show symptoms of a decreased physiological function. These symptoms include changes in the respiration system (gills, breathing frequency) and blood hemoglobin. Cyprinid fish are active fish that require high oxygen levels. In a minimum oxygen condition, cyprinid fish are easy to get stressed. Despite the extensive literature on cyprinid biology, comparison of declined physiological functions due to oxygen depletion in cyprinid are few and far between. The purpose of this study was to determine the physiological reactions and organ responses of three species of Cyprinidae, common carp (Cyprinus carpio), nilem carp (Osteochilus hasselti), and Torsoro carp (Tor soro) challenged to oxygen depletion. The study was conducted using 18 fishes for each species with an average body weight of $48.11 \pm 4.24 \mathrm{~g}$. Oxygen depletion challenge was done by placing the test fish in closed and non-aerated aquaria $(40 \mathrm{~cm} \mathrm{x}$ $20 \mathrm{~cm} \times 20 \mathrm{~cm}$ ). The dissolved oxygen level in each aquarium was measured every 30 minutes. Fish breathing frequency was calculated by the frequencies of mouth movement every 30 minutes. Histological examination of gills and blood was taken from healthy fish (at the beginning of treatment) and at $\mathrm{LC}_{50}$ (lethal concentration). The results showed that oxygen depletion reduced blood hemoglobin levels down to 5.1 $\pm 1.4 \mathrm{gram} \% 3.3 \pm 1.15 \mathrm{gram} \%$ and $1.5 \pm 0.71 \mathrm{gram} \%$ for goldfish, nilem, and torsoro, respectively. The respiratory rate varied from normal to depleted conditions. When depletion occurred, the respiratory rate increased and decreased again when the fish started to get weak. In normal conditions, the breathing frequency of goldfish was 60 beats/minute, nilem was $108 \pm 20.8$ beats/minute, and Tor soro was $144 \pm$ 31.7 beats/minute. The highest respiration frequency occurred in tor soro fish in the 150th minute with a value of $216 \pm 0.0$ beats/minute. The fastest mortality at $\mathrm{LC}_{50} \%$ occurred in torsoro at $245.00 \pm 17.32$ minutes.
\end{abstract}

\section{KEYWORDS: Cyprinidae; oxygen depletion; stress response}

\section{INTRODUCTION}

The oxygen content in water is only $5 \%$ or less compared to that of the air. If dissolved oxygen concentrations drop below a certain level, most higher trophic level organisms, particularly fish, will experience a rising mortality rate. Sensitive freshwater fish like salmon can not reproduce at a DO level below 6 $\mathrm{mg} / \mathrm{L}$. In the ocean, fish will avoid areas where the DO is below $3.7 \mathrm{mg} / \mathrm{L}$ and certain fish species will completely abandon an area when the DO level falls below $3.5 \mathrm{mg} / \mathrm{L}$. Below $2.0 \mathrm{mg} / \mathrm{L}$, invertebrates will leave the area. Under $1 \mathrm{mg} / \mathrm{L}$, sessile benthic organisms show reduced growth and survival rates. (Fondriest, 2013).

\# Correspondence: Research Intitute of Freshwater Aquaculture and Fisheries Extentions.

Sempur street Number 1 Bogor, Indonesia

E-mail: wahyulia.cahyanti@gmail.com
In most cases, a sudden decrease of DO level in waters will stimulate a degree of stress in fish.

The Cyprinidae family prefers to live in flowing and shallow rivers (Mutiara, 2014). Despite the fish family has been farmed in many developing countries, its farming industry still faces many obstacles, including a sudden decrease of oxygen content in the rearing media. Imbalanced oxygen content causes stress in fish (Rosiana, 2017), leading to deteriorated physiological function. Stress due to oxygen depletion can lead to changes in fish respiration system (gills, breathing frequency) and blood hemoglobin (HB) concentration.

A study showed that oxygen depletion levels affected the behavior and ecological responses of Luciobarbus bocagei (Hayes et al., 2019). Studies related to oxygen consumption in barred loach reported 
that oxygen consumption under hypoxic conditions decreased significantly compared to normoxic conditions marked by decreased swimming activities (Iswantari et al., 2019). Rukka (2012) stated that different stocking densities affected the level of oxygen consumption in milkfish, which prefers optimum density (for juvenile milkfish) at 35 fishes per $45 \mathrm{~L}$ rearing media. The higher the density of milkfish, the higher the level of oxygen consumption.

Prakoso et al. (2018) and others have carried out studies on oxygen consumption in carp. However, comparing oxygen consumption in two other economically important carp species, bony lip barb and tor, has not been conducted. Therefore, this present study was conducted to determine the physiological reactions due to oxygen depletion in three species of cyprinid fish, namely common carp, bony lip barb, and torsoro. The information gained from this study is essential for fish farmers to recognize the stress level of fish due to oxygen depletion.

\section{MATERIALS AND METHODS}

The study was conducted at the Research Station of Freshwater Fisheries Germplasm, Cijeruk, Bogor, in September 2018. The variables measured were oxygen depletion, breathing frequency, LC50, gill histology, and blood hemoglobin content. The study was arranged in a completely randomized design (CRD) consisting of three treatments, which were $A$ (common carp), B (bonylip barb), and C (torsoro). The mean weight of fish used was $48.11 \pm 4.24 \mathrm{~g}$, with a number of fish of 18 fishes per species. The tested fish were maintained in an aquarium of $60 \mathrm{~cm} \times 20 \mathrm{~cm} \times$ $20 \mathrm{~cm}$ in size. The fish were starved for 24 hours before starting the trial. The fish were then moved into nine aquaria of $40 \mathrm{~cm} \times 20 \mathrm{~cm} \times 20 \mathrm{~cm}$ in size with a six fish/aquarium stocking density to accommodate three replicates. All aquaria were filled with water and tightly covered to avoid contact between water and outside air.

\section{Oxygen Depletion}

The observation of oxygen depletion response was carried out by placing the fish in a $40 \mathrm{~cm} \times 20 \mathrm{~cm} \times 20$ $\mathrm{cm}$ aquarium, covered and without aeration. Dissolved oxygen in the water of each aquarium was measured using a DO meter (Lutron DO-5510) every 30 minutes. Each aquarium was tightly sealed with a lid. The probe of the DO meter was inserted through a hole on the lid and secured tightly to measure the oxygen content in the rearing media. The decrease of oxygen level per observation was recorded as the oxygen depletion value.

\section{Oxygen Consumption}

Oxygen consumption was measured according to the following formula (Valverde et al., 2006):

$$
\mathrm{MO2}=\frac{([02] \mathrm{t} 1-[02] \mathrm{t} 2) \times \mathrm{V}}{(\mathrm{B} \times \mathrm{V})}
$$

where: M02 is oxygen consumption of individual fish ex-

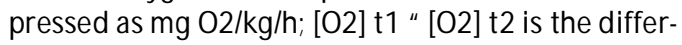
ence in oxygen concentrations (mg 02/L) over measurement time; $V$ is the volume of the tank (L); $B$ is fish biomass $(\mathrm{kg})$, and $\mathrm{t}$ is time $(\mathrm{h})$ during measurement

Breathing frequency was determined by calculating the frequency of mouth movement every 30 minutes. Histological examinations of gills and blood were done on samples taken from control and $\mathrm{LC}_{50}$.

\section{Hb measurement and Gill Histology}

Blood samples were collected using syringes previously washed with anticoagulants (EDTA 3.8\%). The samples were then placed into Eppendorf micro-tubes placed in crunched ice cubes bath. The next step was filling the salinometer tube with $0.1 \mathrm{~N} \mathrm{HCl}$ solution up to the number 10 (bottom line of the scale on the salinometer tube). The tube was placed between two other tubes which contain the standard color. Using a cleaned Sahli pipette tip, $0.02 \mathrm{~mL}$ blood was moved from Eppendorf into a Sahli tube and left for three minutes. Distilled water was slowly added using a pipette while stirring with a stirring glass until the color was the same as the standard color. Hemoglobin levels are stated in gram\%

Gill tissue was taken using scissors and put into a tube containing $70 \%$ alcohol. The histology of the gill tissue structure was carried out according to Windarti $\&$ Simarmata (2015). The sample was fixed with $10 \%$ neutral buffer formalin (NBF), then trimmed (reduced so that it entered the tissue cassette, followed by dehydration with a series concentration of alcohol). Staining used hematoxylin-eosin (HE). Afterward, the histological samples were observed or photographed using an Olympus CX21 microscope. The data were tabulated and statistically analyzed using SPSS ver.16 with a confidence level of $95 \%$

\section{RESULTS AND DISCUSSION}

Oxygen concentration decreased over $180 \mathrm{~min}$ utes of observation. This decreased pattern was suspected as the result of the fish oxygen consumption. Figure 1 illustrates that the DO level in the aquarium continued to decline from 0 to 180 minutes due to the oxygen consumption of fish without air-water diffusion. The DO pattern in the three graphs is rela- 


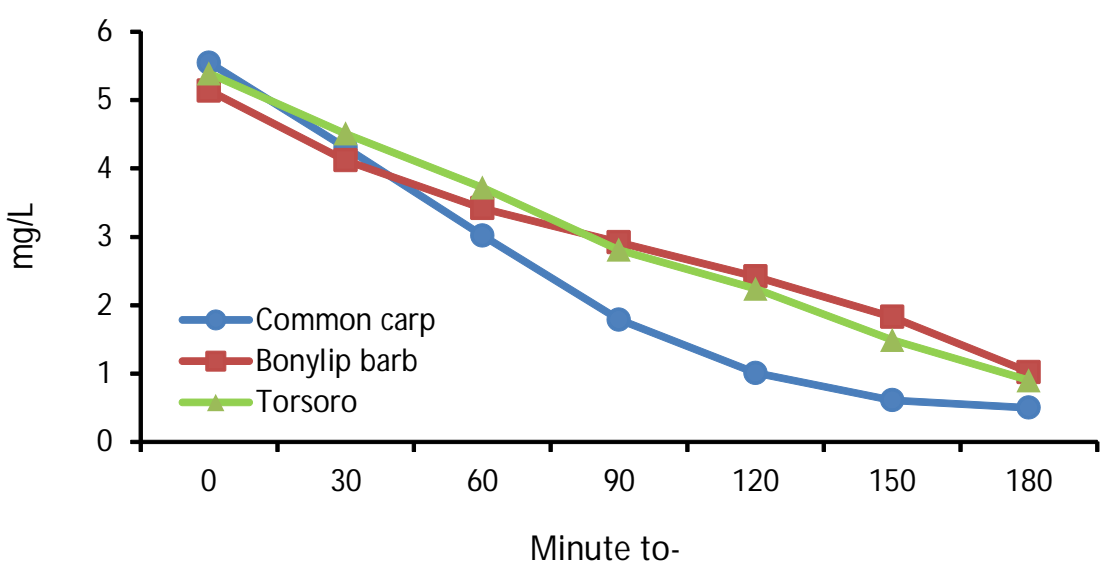

Figure 1. Pattern of oxygen depletion during 180-min observation.

tively similar, where it continues to decline up to the point where fish can no longer tolerate it. The rearing media of the common carp had a faster oxygen reduction rate, followed by the rearing media of torsoro and bony lip barb as the lowest.

Oxygen depletion is the most common cause of fish death in ponds and aquariums. Oxygen depletion in the maintenance medium occurs when the conditions for oxygen demands are greater than the oxygen produced biologically, physically, and chemically. In many cases, farmers are too late to anticipate when the oxygen depletes, which eventually causes the fish to die. As such, oxygen depletion should be anticipated and detected earlier to prevent mortalities (Burtle, 2014).

The DO level in a water body fluctuates depending on its physical, chemical, and biochemical activities (Patel \& Vashi, 2015). Dissolved oxygen plays an important role directly in the physiology of organisms. (Henderson-Sellers \& McGuffie, 2012). At $26^{\circ} \mathrm{C}$ with $50 \%$ oxygen saturation, freshwater contains about $4 \mathrm{mg} / \mathrm{L}$ of dissolved oxygen (Boyd \& Hanson, 2010). In a normal condition without pollutions, water has a minimum $\mathrm{DO}$ concentration of $2 \mathrm{mg} / \mathrm{L}$. The oxygen content that fish can tolerate under hypoxic conditions varies between sizes. For large fish, the DO level is $0.71 \mathrm{mg} / \mathrm{L}$, but smaller-sized fish can survive even until the amount of oxygen in the water is only $0.57 \mathrm{mg} / \mathrm{L}$ (Lakani et al., 2013).

There were differences in oxygen consumption patterns between the fish species. In the first hour, the average value of oxygen consumption was 6.76 $\pm 1.28 \mathrm{mg} \mathrm{O} / \mathrm{g}$ weight/hour for bony lip bar, $8.22 \pm$ $1.53 \mathrm{mg} \mathrm{O} / \mathrm{g}$ weight/hour for common carp $5.51 \pm$ $0.23 \mathrm{mg} \mathrm{O}_{2} / \mathrm{g}$ weight /hour for torsoro. At the second hour, there was a decrease of $\mathrm{O}_{2}$ consumption rate by bony lip barb $\left(3.92 \pm 1.18 \mathrm{mg} \mathrm{O}_{2} / \mathrm{g}\right.$ weight/hour) and common carp (6.56 $\pm 1.21 \mathrm{mg} \mathrm{O_{2 }} / \mathrm{g}$ weight/hour) but relatively stable for torsoro $(5.56 \pm 1.12 \mathrm{mg} \mathrm{O} /$ $\mathrm{g}$ weight/hour). In this second hour, the oxygen consumption by bony lip barb was significantly different from the other two species. However, torsoro and common carp were not significantly different. In the last one hour before death, the average value of oxygen consumption declined again for common carp $(1.62 \pm 0.05)$ and torsoro $(3.74 \pm 0.19)$, while nilem had an increasing trend to $5.48 \pm 2.33$. Unlike the previous two samplings, the third sampling for common carp showed that the oxygen consumption was significantly different from the other two species. However, torsoro and bony lip barb had no significant difference in terms of oxygen consumption. The average value of oxygen consumption in carp is be-

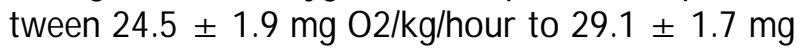
02/kg/hour (Prakoso et al., 2018).

The present studies demonstrated that the three species had different patterns of oxygen consumption. Goldfish had a drastic decrease in oxygen consumption associated with the reduction of oxygen soluble in the water. Torsoro had a similar pattern of oxygen consumption, but the reduction occurred slowly. In the case of nilem, the patterns of oxygen consumption were not clear. Its oxygen consumption can elevate even when the amount of oxygen in the waters decreased. This phenomenon indicates that goldfish have a better ability to adjust their oxygen consumption when oxygen levels decreased in water, compared to tor and nilem.

In the wild, fish might try to escape from unfavorable conditions (Hayes et al., 2019). Barbel and some fish species usually reduce their swimming activity and adopt a "sit and wait" strategy (Domenici et al., 2013). However, in connected pool habitat experiments, barbel fish continued to move despite reduced oxygen levels, possibly searching for higheroxygenated areas. Nevertheless, the number of move- 
Table 1. Average oxygen consumption rate of treated fish

\begin{tabular}{lccc}
\hline \multirow{2}{*}{ Treatment } & \multicolumn{3}{c}{ Oxygen consumptions $\left(\mathbf{m g ~ O}_{\mathbf{2}} / \mathbf{g}\right.$ weight $/$ hour $)$} \\
\cline { 2 - 4 } & First hour & Second hour & Third hour \\
\hline Cyprinus carpio & $8.22 \pm 1.53^{\mathrm{a}}$ & $6.56 \pm 1.21^{\mathrm{a}}$ & $1.62 \pm 0.05^{\mathrm{a}}$ \\
Osteochilus hasselty & $6.76 \pm 1.28^{\mathrm{a}}$ & $3.92 \pm 1.18^{\mathrm{b}}$ & $5.48 \pm 2.33^{\mathrm{b}}$ \\
Torsoro & $5.51 \pm 0.23^{\mathrm{a}}$ & $5.56 \pm 1.12^{\mathrm{a}}$ & $3.74 \pm 0.19^{\mathrm{b}}$ \\
\hline
\end{tabular}

Note: Different superscript letters in the same column show significant differences $(P<0.05)$

ments significantly decreased under low $(15 \%$ DO concentrations (Branco et al., 2016). In deprived oxygen conditions, isolated habitats can pose a threat to fish. A network of interconnected rivers is necessary to ensure that fish can move to other locations to avoid hypoxia.

Respiratory activity in fish can be determined by calculating ventilation settings, defined as when the fish breathe air-saturated water through the mouth and release it through the operculum. The activity is to regulate the amount of water that must be pumped through the gills based on the oxygen demand. The highest value of breathing frequency for common carp, tor fish, and bony lip barb occurred at the 180th minute, 150 th minute, and 180th minute, respectively (Table 2).

Changes in the respiratory rate of fish in minutes $0,30,60,90,120,150,180$, and $\mathrm{LC}_{50}$ can be seen in Table 2. A gradual increase of breathing frequency during the observation was in line with the decrease in oxygen level (Figure 1), most probably because the fish gradually entered the stress condition. At the beginning of the treatment, the fish swam normally with a regular frequency of opening and closing the mouth. However, as oxygen was depleted in the aquariums, the fish respiration became faster, and so did the movement. These behaviors are efforts of fish to adjust to the change of environment due to oxygen depletion (Hayes et al., 2019).
In common carp and bony lip barb, breathing frequency continued to increase until the 180th minute and became weak at $\mathrm{LC}_{50} \%$ For torsoro, the highest frequency occurred at 150 minutes with $216 \pm 0.0$ times/minute and then decreased at 180 minutes and $\mathrm{LC}_{50} \%$ Table 2 showed that the breathing frequencies of the three species were also different at a normal condition where carp, nilem, and tor were only 60 , $108 \pm 20.8$, and $144 \pm 31.7$ times/minute, respectively. These results indicated that tor fish had a faster breathing frequency compared to the other two Cyprinidae species. The difference in the values of the respiratory frequency compared to the control is due to differences in the behavior of the fish in their habitat. Tor fish usually live upstream of rivers or springs where DO is typically high. On the other hand, common carp and bony lip barb live in more varied habitats. It is argued here that the latter two are more adapted to environments with lower oxygen content.

Like terrestrial animals and humans, fish also have specific behaviors in the respiration process. The ultimate goal of breathing is to maintain the proper concentration of oxygen, carbon dioxide, and hydrogen ions in the body. Decreased oxygen concentration stimulates respiratory activity by acting on chemoreceptors. The chemoreceptors then send signals to the brain to stimulate respiratory activity, as shown by respiratory behavior in all three types of treated fish.

Table 2. Breathing frequency of treated fish every 30 minutes of observation

\begin{tabular}{cccc}
\hline Observation & \multicolumn{3}{c}{ Breathing frequency (times/minute) } \\
\cline { 2 - 4 } time & Cyprinus carpio & Osteochilus hasselty & Torsoro \\
\hline 0 & $60 \pm 0.0$ & $108 \pm 20.8$ & $144 \pm 31.7$ \\
30 & $60 \pm 0.0$ & $108 \pm 20.8$ & $172 \pm 13.9$ \\
60 & $132 \pm 0.0$ & $128 \pm 6.9$ & $184 \pm 30.2$ \\
90 & $148 \pm 6.9$ & $148 \pm 13.9$ & $196 \pm 6.9$ \\
120 & $152 \pm 6.9$ & $156 \pm 21.1$ & $200 \pm 48$ \\
150 & $178 \pm 15.1$ & $180 \pm 48$ & $\mathbf{2 1 6} \pm \mathbf{0 . 0}$ \\
180 & $\mathbf{1 8 0} \pm \mathbf{1 2}$ & $\mathbf{2 0 4} \pm \mathbf{2 4}$ & $192 \pm 12$ \\
LC 50\% & $88 \pm 6.9$ & $144 \pm 31.4$ & $166 \pm 0.0$ \\
\hline
\end{tabular}


The respiratory rate of fish is shaped like a curve where breathing frequency will increase gradually due to stress until it reaches a maximum. This is directly proportional to swimming speed. When reaching the maximum breathing frequency, swimming speed decreases due to fatigue and decreased oxygen levels. According to Sahetapy (2013), oxygen is a limiting factor for the activity and life of all living things because all cell activities require oxygen.

The concentration of $\mathrm{Hb}$ measured in fish at the beginning and end of the experiment in all treatments showed differences among the fish species (Table 3). The $\mathrm{Hb}$ value of stressed fish was higher than those measured at the beginning of the experiment. The highest obtained value in common carp was $5.1 \pm$ 1.41 , significantly different from the other two species. The $\mathrm{Hb}$ physically has an essential relationship with oxygen. The function of hemoglobin is to carry oxygen to all parts of the body. The average hemoglobin level of tilapia is low in the range of $4.13 \mathrm{G} \%$ $\pm 4.67 \mathrm{G} \%$ because normal hemoglobin levels are from 5.05 to $8.33 \mathrm{G} \%$ (Royan et al., 2014).

Hemoglobin $(\mathrm{Hb})$ is a protein consisting of protoporphyrin, globin, and iron in the form of ferrous. One gram of hemoglobin can bind around $1.39 \mathrm{~mL}$ of oxygen (Pittman, 2011). Hematological and hematochemical responses (one of them hemoglobin) are quantitatively related to the severity and duration of stress (Fazio et al., 2015). Hemoglobin is essential for oxygen transport from the gills to the tissues. Another primary function of $\mathrm{Hb}$ is as an "oxygen buffer" system responsible for regulating oxygen pressure in the tissue. This is related to the essential role of hemoglobin to facilitate or accelerate oxygen diffusion (Carneiro et al., 2009). In addition, the ability to transport oxygen in the blood depends on the $\mathrm{Hb}$ levels in erythrocytes. The red color of fresh blood is caused by the presence of $\mathrm{Hb}$ in red blood cells.

In torsoro, the $\mathrm{Hb}$ value was relatively low in stressed fish and not detected in healthy fish due to limited blood samples taken from small fish of 48.11 $\pm 4.24 \mathrm{~g}$ (sampling blood from a $50 \mathrm{~g}$ fish is difficult). Alternatively, the blood was sampled directly from the heart suspected to not pass through the lungs. When erythrocytes pass through the gill capillaries, hemoglobin binds to oxygen to form oxyhemoglobin. Conversely, when it passes through the systemic capillaries, hemoglobin releases oxygen to the tissues and binds carbon dioxide. The carbon dioxide is brought back to the gills for disposal.

Environmental disturbances such as extreme temperatures, osmotic, poison, infection, or social pressure can stimulate stress. Several symptoms as the effects of stress in fish include decreased blood volume and leukocytes, decreased liver glycogen, and increased blood glucose. The adverse effects of stress in fish can also reduce the diameter of the stomach and the depletion of the mucous lining (Carneiro et al., 2009).

Gill tissue had noticeable damages with different levels in all treatments where the most severe damage occurred in torsoro followed by nilem and goldfish. The damages were illustrated by histological changes shown in Table 3.

In normal gills, lamellae have a regular structure, both primary and secondary lamellae, cartilage tissue containing blood vessels looks dense. However, the gills of stressed fish due to lack of oxygen have messy lamellae, and some parts look swollen and cracked. Some are even crushed to the secondary lamella. Gills damaged will be very detrimental to cultivators. According to Baxter et al. (2011), gill disturbances have become one of the most severe causes of death in sea-farmed salmon in Ireland.

The arrow in figure $2 \mathrm{~A}$ shows the normal structure of cartilage tissue that is still intact, and the blood vessels are still solid, while figure $2 B$ shows damaged gill and ruptured blood vessels. The arrow in figure $2 \mathrm{C}$ shows a good primary lamella tissue, while in figure 2D, primary lamella is damaged. The arrow in figure 2E shows nice and neat secondary lamella tissue, while the secondary lamella in figure $2 \mathrm{~F}$ is damaged.

In fish, gills are an important component in gas exchange. Gills also act as organs capable of passing water or minerals and removing metabolic waste. Gills

Table 3. Value of hemoglobin at initial and at $\mathrm{LC}_{50}$ of fish under oxygen depletion

\begin{tabular}{lcc}
\hline \multirow{1}{*}{ Fish } & \multicolumn{2}{c}{ Hemoglobin (gram \%) } \\
\cline { 2 - 3 } & Initial fish & LC $_{50} \%$ fish \\
\hline Cyprinus carpio & $2 \pm 0.00$ & $5.1 \pm 1.40$ \\
Osteochilus hasselty & $2 \pm 0.00$ & $3.3 \pm 1.15$ \\
Tor soro & $0 \pm 0.00$ & $1.5 \pm 0.71$ \\
\hline
\end{tabular}



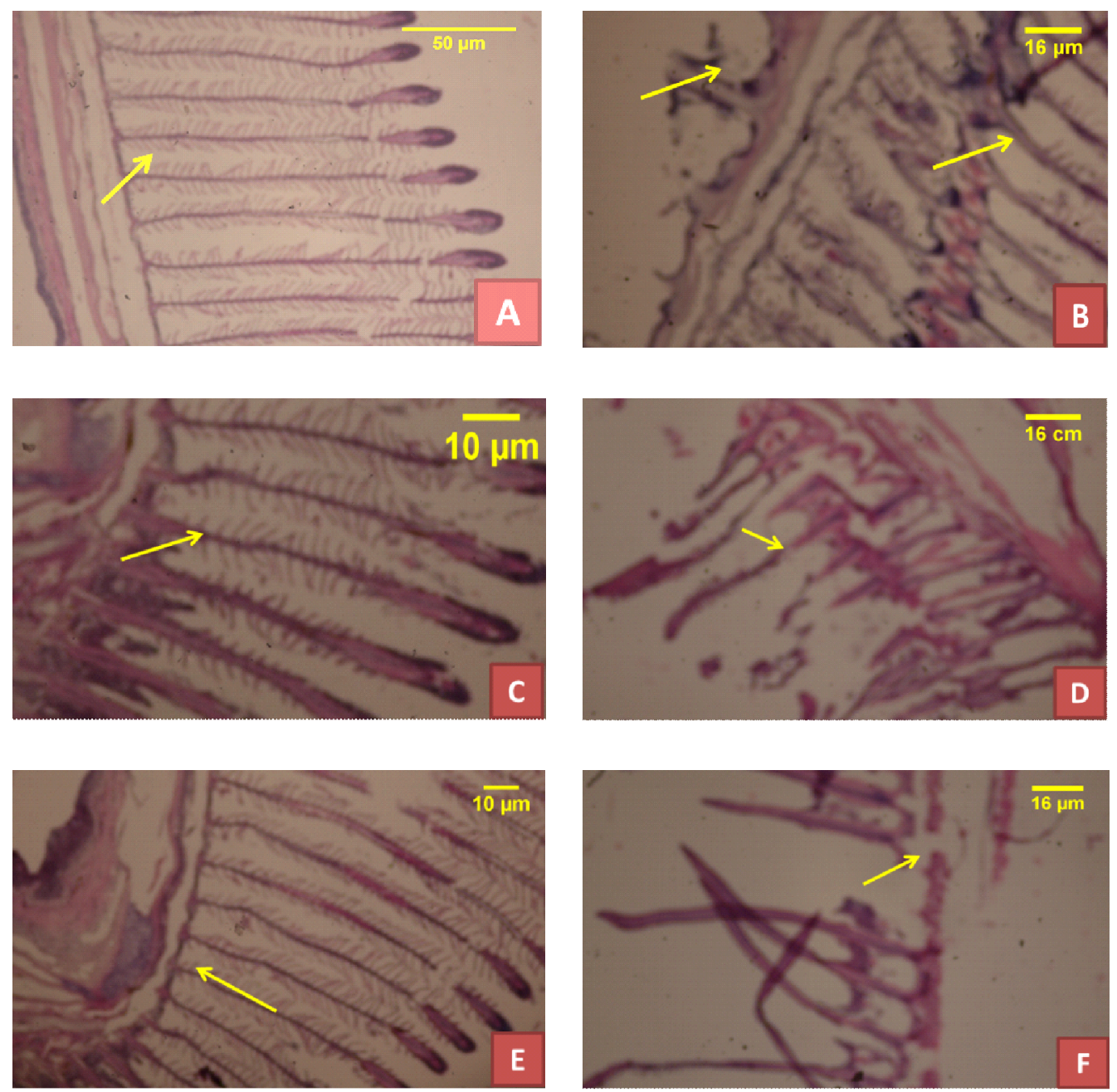

Figure 2. Histological preview of healthy and stressed fish gills: (A) healthy gills of common carp; (B) gills of stressed common carp; (C) healthy gills of bony lip barb fish; (D) gills of stressed bony lip barb fish; (E) healthy torsoro gills; and (F) gills of stressed torsoro.

have a specific histological structure formed by hardened cartilage arches. The gill sheet (hemibranch) consists of gill filaments (primary lamella), and each filament (primary lamella) is composed of secondary lamellae.

Lethal time is determined when the test fish dies at $50 \%$ of the total number of test fish. Torsoro had a faster $\mathrm{LC}_{50}$ time, while common carp had the longest $\mathrm{LC}_{50}$ time, as shown by Table 4 . These results demonstrated that although the three species belong to cyprinids, each species has a significantly different time for $\mathrm{LC}_{50} \%$ Bony lip barb was more resistant, with $\mathrm{LC}_{50} \%$ occurred at $418.33 \pm 16.07$ minutes, while torsoro was the most sensitive fish to die with $\mathrm{LC}_{50} \%$ at $245.00 \pm 17.32$ minutes.

The leading cause of the difference in $\mathrm{LC}_{50} \%$ time is presumably not due to oxygen consumption if seen by the relatively similar patterns of oxygen consumption between species. This difference is thought to be more influenced by different activities and behaviors. Torsoro is the most active species compared to nilem and goldfish. More active fish will need more oxygen to reduce dissolved oxygen in the water more quickly. In contrast to goldfish, continuous oxygen depletion slowly reduced the fish movement. Oxygenation in the treatment was indicated by a very low dissolved oxygen content in the aquaria caused by the decomposition of organic material coming from feces. The low oxygen contents were also because of fish breathing. In other words, the oxygen content in the water becomes very low when the fish release impurities. Decomposition of impurities requires oxygen. The more dirt decomposes, the more oxygen is consumed. As a consequence, the fish will have difficulty in breathing. 
Table 4. The lethal time $\left(\mathrm{LC}_{50}\right)$ of fish treated by oxygen depletion

\begin{tabular}{lc}
\hline \multicolumn{1}{c}{ Fish } & LC $_{\mathbf{5 0}}$ \%time (minute) \\
\hline Cyprinus carpio & $418.33 \pm 16.07^{\mathrm{a}}$ \\
Osteochilus hasselty & $366.67 \pm 29.30^{\mathrm{b}}$ \\
Torsoro & $245.00 \pm 17.32^{\mathrm{c}}$ \\
\hline
\end{tabular}

Note: Superscript letters in the same column show significant differences $(P<0.05)$

\section{CONCLUSION}

Oxygen depletion tends to reduce blood hemoglobin levels. When depletion occurred, the respiratory rate increases and then decreases as the fish starting to get weak. The highest frequency of respiration occurred in torsoro fish (150th minute, when depletion occurred), which was $216 \pm 0.0$ beats/ minute. The fastest mortality due to $\mathrm{LC}_{50} \%$ occurred in torsoro at $245.00 \pm 17.32$ minutes. Oxygen depletion stimulated stress in Cyprinidae fish, indicated by increased breathing frequency and blood hemoglobin levels and gill damage. This study can aid fish farmers in properly maintaining suitable water quality conditions specifically for each of the fish species to achieve optimal culture harvest.

\section{ACKNOWLEDGEMENTS}

The authors thank the Head of Research Institute of Freshwater Aquaculture and Fisheries Extension for research support and access to research facilities. The authors also thank M. Yunus, A.Md. and Deni Irawan for their technical assistance, cooperation, and help to complete this research.

\section{REFERENCES}

Fondriest. (2013). "Dissolved oxygen." Fundamentals of Environmental Measurements. Fondriest Environmental, Inc. https://www.fondriest.com/environmental-measurements/parameters/water-quality/dissolved-oxygen/ > . Accessed 09 June 2021 at 13.18.

Baxter, E., Sturt, M.M., Ruane, N.M., Doyle, T.K., McAllen, R., Harman, L., \& Rodger, H.D. (2011). Gill damage to Atlantic salmon (Salmo salar) caused by the common jellyfish (Aurelia aurita) Under Experimental Challenge. PLoS One, 6(4), e18529. Published online. DOI: 10.1371/journal.pone.0018529.

Boyd, C. \& Hanson, T. (2010). Dissolved-oxygen concentration in pond aquaculture. Global Aquacult. Advocate, 13, 40-41.

Branco, P., Santos, J.M., Amaral, S., Romão, F., Pinheiro, A.N., \& Ferreira, M.T. (2016). Potamodromous fish movements under multiple stressors: Connectivity reduction and oxygen depletion. Science of The Total Environment, 572, 520-525. https://doi.org/10.1016/ j.scitotenv.2016.08.070.

Burtle, G.J. (2014). Oxygen depletion in ponds. UGA Extension Circular 1048.

Carneiro, P.C.F., Kaiseler, P.H. da S., Swarofsky, E. de A.C., \& Baldisserotto, B. (2009). Transport of jundiá Rhamdia quelen juveniles at different loading densities: Water quality and blood parameters. Neotropical Ichthyology, 7(2), 283-288. https:// doi.org/10.1590/S1679-62252009000200021.

Domenici, P., Herbert, N.A., Lefrançois, C., Steffensen, J.F., \& McKenzie, D.J. (2013). The effect of hypoxia on fish swimming performance and behaviour. In Palstra, A.P. \& Planas, J.V. (Eds.). Swimming physiology of fish: Towards using exercise to farm a fit fish in sustainable aquaculture. p. 129-159. Springer Berlin Heidelberg. https:/ /doi.org/10.1007/978-3-642-31049-2_6.

Fazio, F., Ferrantelli, F., Fortino, G., Arfuso, F., Giangrosso, G., \& Faggio, G. (2015). The influence of acute handling stress on some blood parameters in cultured sea bream (Sparus aurata Linnaeus, 1758). Ital J. Food Saf., 4(1), 4174. doi: 10.4081/ijfs.2015.4174.

Hayes, D.S., Branco, P., Santos, J.M., \& Ferreira, T. (2019). Oxygen depletion affects kinematics and shoaling cohesion of cyprinid fish. Water, 11(4), 642. https://doi.org/10.3390/w11040642.

Henderson-Sellers, A. \& McGuffie, K. (2012). The future of the world's climate. Elsevier Inc. $650 \mathrm{pp}$. https://doi.org/10.1016/C2010-0-67318-4\&.

Iswantari, A., Kurniawan, K., Priadi, B., Prakoso, V.A., $\&$ Kristanto, A.H. (2019). Oxygen consumption of barred loach Nemacheilus fasciatus (Valenciennes, 1846) under different stocking densities. OLDI (Oseanologi dan Limnologi di Indonesia), 4(2), 7987. (Indonesian with English abstract). DOI: 10.14203/oldi.2019.v4i2.245.

Lakani, F.B., Sattari, M., \& Falahatkar, B. (2013). Effect of different oxygen levels on growth performance, stress response and oxygen consumption in two weight groups of great sturgeon Huso huso. Iranian Journal of Fisheries Sciences, 12(3), 533-549. 
Mutiara, D. (2014). Classification of species of fish in the family Cyprinidae in the Pangi River, Pengumbuk Village, Rantau Bayur District, Banyuasin Regency, South Sumatra Province. Jurnal Sainmatika, 11(1), 37-41.

Patel, H. \& Vashi, R.T. (2015). Characterization and treatment of textile wastewater. Elsevier Inc. https://doi.org/10.1016/B978-0-12-802326-6.099950.

Prakoso, V.A., Ryu, J.H., \& Chang, Y.J. (2018). Diel rhythm of oxygen consumption on adult common carp Cyprinus carpio with continuous 24-hours photoperiod. Jurnal Sains Natural, 8(1), 1. (Indonesian with English abstract). https://doi.org/ 10.31938/jsn.v8i1.105.

Pittman, R.N., (2011) Regulation of tissue oxygenation. Morgan \& Claypool Life Sciences. https:// www.ncbi.nlm.nih.gov/books/NBK54108/. Accessed 09 June 2021 at 10.05.

Rosiana, L. (2017). Water Quality Analysis of Koi Fish (Cyprinus carpio) indicated by KHV (Koi Herpes Virus) in rearing ponds in Kemloko Village, Legok
District, Blitar Regency, East Java. Thesis. Universitas Brawijaya. Malang.

Royan, F., Rejeki, S., \& Haditomo, A.H.C. (2014). The effects of different salinity on blood profile parameters of tilapia (Oreochromis niloticus). Journal of Aquaculture Management and Technology, 3(2), 109-117. (Indonesian with English abstract).

Rukka, D.P. (2012). Effect of Different Density on Oxygen Consumption in Milkfish Juvenile (Chanos chanos Forsskal). Thesis. Universitas Hasanudin. Makassar.

Sahetapy, J.M.F. (2013). The effects of difference water volume to the oxygen consumption of nile tilapia (Oreochromis sp.). Jurnal TRITON, 9(2), 127-130. (Indonesian with English abstract).

Valverde, J.C., Martínez López, F.J., \& García, B.G. (2006). Oxygen consumption and ventilatory frequency responses to gradual hypoxia in common dentex (Dentex dentex): Basis for suitable oxygen level estimations. Aquaculture, 256, 542-551.

Windarti \& Simarmata, A.H. (2015). Textbook Network structure. UNRI Press, 105 pp. 